\title{
PHYSICO-CHEMICAL PECULIARITIES OF WEIGHTED THERMOSTABLE PLUGGING MATERIALS HYDRATION
}

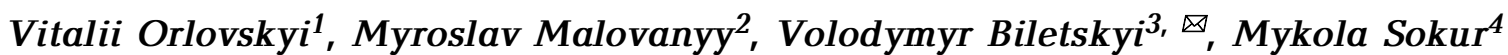

https://doi.org/10.23939/chcht15.04.599

\begin{abstract}
A new competitive class of plugging compositions (weighted non-shrink plugging materials) has been created using as components a fly ash from thermal power station, a weighting additive and a superplasticizer. X-ray phase analysis identified the composition of new materials formed in the hydration process of the developed plugging compositions. The kinetic curves of the plugging material expansion in a wide temperature range have been obtained. Rational temperature regimes of plugging materials hardening according to the criteria of strength and gas permeability of cement stone have been determined.
\end{abstract}

Keywords: oil-well cementing, plugging material, cement hydration, fly ash, water-mixture ratio, cement stone.

\section{Introduction}

In recent years, the number of oil and gas fields that are being drilled under difficult mining and geological conditions is increasing. As a result, stricter requirements are put forward for plugging materials used in deep oil and gas wells. This is especially true for cements intended for well fixing in deposits with abnormally high formation pressure (AHFP) at the depth of 4000-6000 m. In addition, at the depth of $4000 \mathrm{~m}$ and higher formation temperatures significantly exceed $373 \mathrm{~K}$. Therefore, there is a problem of creating high-density plugging materials with high performance properties. At the same time, in the face of increasing ecological problems (pollution of the hydrosphere by ammonium ions $[1,2]$, heavy metals $[3$, 4], organic compounds and petroleum products [5], atmospheric pollution [6,7], accumulation of industrial waste $[8,9]$ and solid household waste $[10,11])$ and

\footnotetext{
${ }^{1}$ O. M. Becketov National University of Urban Economy in Kharkiv,

17, Marshal Bazhanov St., 61002 Kharkiv, Ukraine

${ }_{2}^{2}$ Lviv Polytechnic National University,

12, S.Bandery St., 79013 Lviv, Ukraine

${ }^{3}$ National Technical University "Kharkiv Polytechnic Institute",

21, Kirpichova St., 61002 Kharkiv, Ukraine

${ }^{4}$ Kremenchuk Mykhailo Ostrohradskyi National University,

20, Pershotravneva St., 39600 Kremenchuk, Ukraine

biletsk@i.ua

(c) Orlovskyi V., Malovanyy M., Biletslyi V., Sokur M., 2021
}

reducing stocks of high-quality raw materials, an application of wastes for the production of binders is a promising direction $[12,13]$.

It is known that there are four most common ways to weight plugging materials [14]:

1) the introduction of weighting additives by mixing them with a binder;

2) the use of ore cements, the density of which is much higher than ordinary Portland cements;

3) joint grinding of clinker and weighting additives; cement.

4) the increase of iron oxide content in Portland

The widest range of density control can be obtained by the first method.

Depending on the base of the mineral, the weighting additives are divided into barite (barite $\mathrm{BaSO}_{4}$, density $4480 \mathrm{~kg} / \mathrm{m}^{3}$ ), iron (hematite $\mathrm{Fe}_{2} \mathrm{O}_{3}$, density $\left.5300 \mathrm{~kg} / \mathrm{m}^{3}\right)$; magnetite $\left(\mathrm{FeO} \cdot \mathrm{Fe}_{2} \mathrm{O}_{3}\right.$, density 4900 $5200 \mathrm{~kg} / \mathrm{m}^{3}$ ); magnetite sand (chemical composition in wt \%: $\mathrm{SiO}_{2} 31.43, \mathrm{Fe}_{2} \mathrm{O}_{3}$ 49.00, $\mathrm{CaO} 11.25, \mathrm{MgO} 7.13$, $\mathrm{MnO} 0.98$; grain size $0.3-0.4 \mathrm{~mm}$; density 3900 $3920 \mathrm{~kg} / \mathrm{m}^{3}$ ), ilmenite (titanium iron ore $\mathrm{FeO} \cdot \mathrm{TiO}_{2}$, density $4720 \mathrm{~kg} / \mathrm{m}^{3}$ ), carbonate (siderite $\mathrm{FeCO}_{3}$, density $3800 \mathrm{~kg} / \mathrm{m}^{3}$ ), lead (galena $\mathrm{PbS}$, density $7500 \mathrm{~kg} / \mathrm{m}^{3}$ ), lead slag (chemical composition in wt \%: $\mathrm{SiO}_{2} 34.0, \mathrm{Al}_{2} \mathrm{O}_{3} 1.5$, $\mathrm{FeO} 40.5, \mathrm{CaO} 21.0, \mathrm{MgO} 1.0$; density $3800-3900 \mathrm{~kg} / \mathrm{m}^{3}$ ), ferroalloys (ferrosilicon, density $6520 \mathrm{~kg} / \mathrm{m}^{3}$; spiegeleisen; silicospiegel - special cast iron alloys, crushed to a particle size of $0.15-0.20 \mathrm{~mm}$, which include iron, carbon, silicon, manganese, chromium and other alloy additions), quartz sand (grain $0.1-0.6 \mathrm{~mm}$, density $2600-2670 \mathrm{~kg} / \mathrm{m}^{3}$ ).

Ash with a high content of the active forms of $\mathrm{SiO}_{2}$ and $\mathrm{Al}_{2} \mathrm{O}_{3}$ contained in the mineral additive [12], can serve as a binder providing non-shrinkage.

Any powdered substance with a high content of silica may be used as an active mineral impurity. We used acid ashes after coal burning at Ukrainian TPP.

Weighted plugging materials are characterized by a reduced water-cement ratio, as a result of which they usually have low spreadability. Therefore, in such solutions, reagents-retarders and plasticizers are additionally used: sulfite waste liquor, condensed sulfite waste liquor, synthetic tartaric acid, hypan, potassium bichromate, oxyl and others. Moreover, the compositions using weighting 
additives have unstable and sedimentationally unstable plugging solutions. This complicates the process of their preparation and significantly affects the quality of oil-well cementing $[14,15]$.

Today in Ukraine the PJSC "Plant of weighting additives" (Kostiantynivka, Ukraine) produces a number of plugging cements based on oil-well Portland cement and smelter slag using quartz sand and iron ore as the weighting additives. Among them are cements: $\mathrm{UCG}-1$, UCG -2 and UShC $-1-120$, UShC $-2-120$, UShC $-1-$ 200, UShC $-2-200$.

UCG - 1and UCG -2 are intended for preparation of plugging solutions with the density of 2060-2150 and $2160-2250 \mathrm{~kg} / \mathrm{m}^{3}$, respectively. Oil-well Portland cement (up to $50 \%$ ) for moderate temperatures or structural Portland cement of grade 400 and higher are used as binders; iron ore (Kryvyi Rih, Ukraine) ground to a specific surface of $220-250 \mathrm{~m}^{2} / \mathrm{kg}$ is used as a weighting additive. Cements are produced by thoroughly mixing of the components. UCG -1 and UCG -2 are used for cementing wells with AHFP at the temperatures of 293$373 \mathrm{~K}$. Among disadvantages of these cements there is a quick loss of their properties during storage [14].

Weighted slag cements UShC-1-120, UShC-2-120, UShC-1-200, UShC-2-200 are produced by a joint grinding of blast furnace sludge (not less than $25 \%$ ), iron ore or other weighting additives with a density of not less than $4000 \mathrm{~kg} / \mathrm{m}^{3}$ (not more than $75 \%$ ) and plugging Portland cement for moderate temperatures of PCT-I-100, or PCT-II-100 brand or construction Portland cement of grade 400 and above (not more than $20 \%$ ). These cements are intended for cementing of oil and gas wells with AHFP in the temperature range of 353-423 K [14].

However, weighted mortars based on abovementioned cement are sedimentationally unstable, have high water separation, low spreadability and do not cover the entire range of densities required for cementing wells with AHFP; in addition, the stone has a low flexural strength. This leads to significant complications and reduced quality of cementation [14]. In addition, during the hardening of such cements, a shrinking stone is formed. Therefore, the problem of creating high-quality plugging materials of high density is urgent.

Numerous studies by a number of authors show that the main factors influencing the phase composition of cementing materials in deep wells are temperature, pressure and duration of the hardening process. Moreover, the temperature is playing a decisive role $[16,17]$.

There are various explanations for the negative effect of temperature on the technological properties of Portland cement, but most researchers connect the deterioration of physical and mechanical properties at the temperatures above $353-363 \mathrm{~K}$ with the formation of highly basic calcium hydrosilicates of $\mathrm{C}_{2} \mathrm{SH}(\mathrm{A})$ type $\left(2 \mathrm{CaO} \cdot \mathrm{SiO}_{2} \cdot \mathrm{H}_{2} \mathrm{O}\right.$, modification $\left.\mathrm{A}\right)[18]$.
It has been shown that at high temperatures, the hydration products of Portland cement or other binder containing calcium oxide interact with silica to form various compounds depending on its content in the mixture. At a low content of $\mathrm{SiO}_{2}$ (up to $20 \%$ ) it binds with $\mathrm{Ca}(\mathrm{OH})_{2}$, which is released during hydration and forms $\mathrm{C}_{2} \mathrm{SH}(\mathrm{A})$, i.e. increases the content of undesirable new formations. At high silica content, it interacts with $\mathrm{C}_{2} \mathrm{SH}$ (A) with the release of low-basic calcium hydrosilicates of tobermorite type (aqueous calcium silicate of layered structure) and, thus, increases the strength of the stone $[19,20]$.

Plasticizers, in particular oxyaminopolycarboxylic acids, natural and synthetic tannins, lignosulfonates, oxidized lignins, etc., are used during drilling to improve the rheological properties of cement slurry. The most known of them are polyphenolic wood-chemical reagent, condensed sulfite waste liquor, oxyl, borax, sulfonol, spent sulfite liquor, etc. [21]. All these reagents are not effective enough, so the search for a solution to the problem was conducted among a class of so-called superplasticizers, developed in the 1970s [22]. Modified melamine-formaldehyde and naphthalene-formaldehyde resins have become widespread in Ukraine [23, 24]. For the first time in the practice of well cementing (in 1980) Poltava branch of the Ukrainian Research Geological Exploration Institute developed the superplasticizer MFAR (modified melamine-formaldehyde resin). At the same time, the superplasticizer C-3 was investigated as an additive to the cement materials [25].

MF-AR and C-3 proved to be almost equivalent regarding their effect on a standard cement slurry. The main difference is that MF-AR better plasticizes Portland cement dispersions, and $\mathrm{C}-3$ acts more effectively on cement mixtures with chlorine-containing salts $(\mathrm{NaCl}$, $\mathrm{KCl}$, etc.). The delivery of imported melamine, which is a raw material for the production of MF-AR, is very limited, but C-3 is produced at Ukrainian enterprises.

However, the peculiarities of autoclave cements (e.g., ash mixtures) hydration - a chemical reaction with water to form crystal hydrates, as a result of which a liquid (plastic) cement mortar is converted into a cement stone under thermobaric conditions of wells, are insufficiently studied. The study of cement hydration kinetics, in which there are stages of thickening and hardening are also of theoretical and practical interest.

The purpose of this work was to study the physicochemical peculiarities of hydration of weighted heatresistant non-shrink plugging materials and regularities of their hardening process, as well as to study the kinetics of plugging material expansion during its hardening. To achieve this goal, the following research objectives were set: 
- to study the hydration products composition of weighted non-shrink plugging materials which are mixtures hardened for a long time at high temperatures;

- to study the kinetic expansion of plugging material during the hardening process, analysis of expansion curves in terms of effect of physico-chemical factors on the rate of hardening;

- to study the dependence of the technological properties of weighted plugging materials based stone on physico-chemical factors, in particular, the composition of the plugging mixture, temperature, pressure and hardening time.

\section{Experimental}

\subsection{Materials}

The investigated cement stone was obtained from a cement mixture, consisting of Portland cement PCT I-100; high-calcium ash; acid ash from Kurakhiv and Ladyzhyn state district power plant (SDPP); barite as a weighting additive, $\mathrm{C}-3$ plasticizer, saturated $\mathrm{KCl}$ solution as a mixing liquid and technical (tap) water.

Cement PCT I-100 of the following composition was produced at PJSC "Ivano-Frankivskcement": clinker with normalized mineralogical composition (75-95\%), special additives (up to $20 \%$ ) and calcium sulfate (up to $5 \%)$.

High-calcium fly ash of Estonian shales is a light yellow powder with a density of $2800-2950 \mathrm{~kg} / \mathrm{m}^{3}$. There are two types of ash: after cyclone and after electrical filter. The specific surface of the first one is 80 $110 \mathrm{~m}^{2} / \mathrm{kg}$, the second one - about 4 times higher.

The chemical composition of cyclone ash (wt \%): $\mathrm{CaO} 40-45$ (free $\mathrm{CaO} 12-20$ ), $\mathrm{SiO}_{2} 26-28, \mathrm{Al}_{2} \mathrm{O}_{3} 6-8$, $\mathrm{Fe}_{2} \mathrm{O}_{3}$ 4.5-5.0, $\mathrm{MgO} 4-5$.

The chemical composition of the electrofilter ash (wt \%): $\mathrm{CaO}$ 30-33 (free $\mathrm{CaO}$ 6.5-7.0), $\mathrm{SiO}_{2}$ 30-32, $\mathrm{Al}_{2} \mathrm{O}_{3} 7-8, \mathrm{Fe}_{2} \mathrm{O}_{3}$ 4.0-4.5, $\mathrm{MgO}$ 4.0-4.5. As a rule, a mixture of cyclone and electrofilter ash is supplied, so some fluctuations in its properties are possible.

Acid fly ash from Kurakhiv SDPP is a powder of dark gray color, with density of $1980-2000 \mathrm{~kg} / \mathrm{m}^{3}$, specific surface area of $350-420 \mathrm{~m}^{2} / \mathrm{kg}$ and bulk weight of $1100-1150 \mathrm{~kg} / \mathrm{m}^{3}$. The chemical composition of ash (wt \%): $\mathrm{SiO}_{2}$ 52-54, $\mathrm{Al}_{2} \mathrm{O}_{3}$ 15-24, $\mathrm{Fe}_{2} \mathrm{O}_{3}$ 17-22, $\mathrm{CaO}$ 2.2-6.0.

Acid fly ash from Ladyzhyn SDPP is a greenishgray powder with the density of $2400-2500 \mathrm{~kg} / \mathrm{m}^{3}$, specific surface area of $210-220 \mathrm{~m}^{2} / \mathrm{kg}$ and bulk weight of $1500-1600 \mathrm{~kg} / \mathrm{m}^{3}$. The chemical composition of ash (wt \%): $\mathrm{SiO}_{2} 57, \mathrm{Al}_{2} \mathrm{O}_{3} 23, \mathrm{Fe}_{2} \mathrm{O}_{3} 11, \mathrm{CaO} 2.0, \mathrm{MgO} 2$.
As can be seen from the comparison of properties of two acid ashes, to create weighted compositions it is better to use the ash from Ladyzhyn SDPP, which has a higher density. This makes it possible in some cases (when the required density of the cement slurry is up to $2000 \mathrm{~kg} / \mathrm{m}^{3}$ ) not to apply a weighting additive and investigate the system of high-calcium ash - acid ash (Ladyzhyn).

Barite $\left(\mathrm{BaSO}_{4}\right)$ was used as a weighting additive, which is superior to hematite, magnetite, and gelenite in its dispersion and hydrophilicity. Barite is a light gray powder (sometimes due to the presence of impurities may be of white, gray, pink, red, yellow or brown color) which contains up to $10-15 \mathrm{wt} \%$ of silica and iron oxide. The density ranges from 4200 to $4700 \mathrm{~kg} / \mathrm{m}^{3}$; bulk weight varies from $1900 \mathrm{~kg} / \mathrm{m}^{3}$, in a loose state during shaking to $3000 \mathrm{~kg} / \mathrm{m}^{3}$.

Previous experiments demonstrated that the simple mixing of high-calcium ash, acid ash and weighting additives did not allow to achieve the desired result in the quality of cement stone.

Weighted plugging materials (WPM) do not have sufficient mobility at a density of more than $1950 \mathrm{~kg} / \mathrm{m}^{3}$ (with the acid ash of Kurakhiv SDPP) and more than $2000 \mathrm{~kg} / \mathrm{m}^{3}$ (with the acid ash of Ladyzhyn SDPP). If we reduce the content of the solid phase, the disintegration of cement slurry occurs. It means that it is necessary to increase the system filling, which can be done only by reducing the water-mixture ratio using the thinners (plasticizers) of cement dispersions.

Based on the literature data, we chose C-3 superplasticizer as an additive to plugging materials. It is a mixture of polymethylnaphthalenesulfonic acids salts, sodium sulfate and sodium salt of lignosulfonic acid, dissolved in water. It is a brown liquid with a density close to the density of water, which contains up to 30 $35 \mathrm{wt} \%$ of the dry matter. It dissolves well in both water and mineralized solutions.

\subsection{Procedures and Instruments}

The plugging solutions were prepared according to the standard procedure using a paddle mixer with a rotation speed of $1500 \pm 100 \mathrm{~min}^{-1}$. Tap water was taken in accordance with a certain water-mixture ratio (W/M). The W/M ratio was determined based on the spreadability of the plugging solutions using a flow cone. According to the standards (flow-table test), the spreadability of plugging solutions should be in the range of $0.18-0.22 \mathrm{~m}$.

The properties of the solutions were evaluated by a sedimentation stability and speed of water segregation, which were determined by standard methods.

The density of plugging solutions was determined using a $100 \mathrm{~cm}^{3}$ calibrated pycnometer with a predetermined weight $m_{1}$ (pure and dry) in grams. 
Water segregation was determined by standard methods. For Portland cements, the amount of water segregated was not more than 7.5-10 $\mathrm{ml}$ [26]. Autoclaving of samples was carried out using AU-1-71-IE installation (Poltava, Ukraine) with the maximum working pressure of $100 \mathrm{MPa}$ and the maximum temperature of $523 \mathrm{~K}$ (Fig. 1). The installation consists of autoclaves, hook-up, control and measuring devices for temperature, pressure and current in the heating system of autoclaves [26].

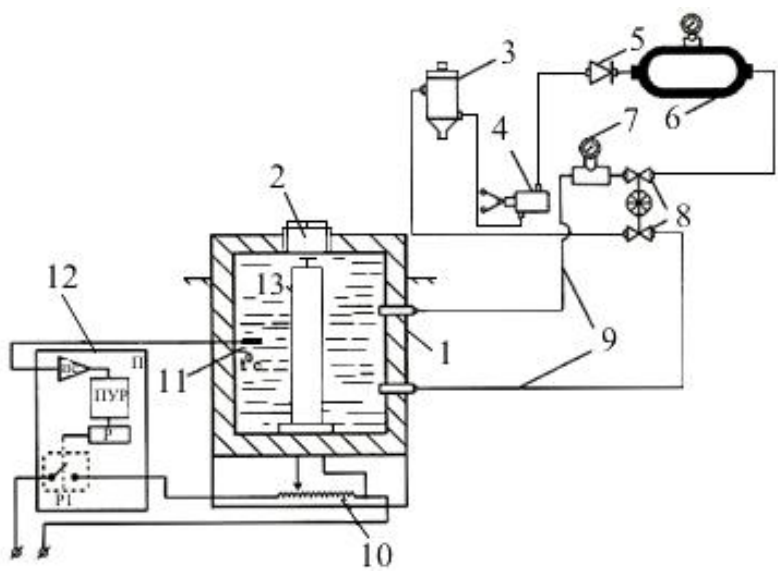

Fig. 1. Schematic drawing of AU-1-71-IE installation: autoclave (1); locking arm of the autoclave (2); waste tank with oil (3); manual press PR-2 (4); check valve (5); working tank with oil (6); manometer (7); high pressure valves (8); autoclave trunk

(9); heating element (10); thermocouple (11); control

transformer (12) and a block with cement samples (13)

The samples were prepared in the form of cylinders (diameter $0.03 \mathrm{~m}$; height $0.03 \mathrm{~m}$ ) and beams $(0.04 \times 0.04 \times 0.16 \mathrm{~m})$. The samples were collected in a battery, according to the working volume of autoclaves, and placed in a preheated environment.

Despite the fact that the mechanical strength of the stone formed in the laboratory can not fully reproduce all technological properties of plugging materials, today it is one of its main evaluation characteristics. Determination of the strength limits of cement stone (bending tension and compressive strength) was carried out according to the typical procedure [26].

Determination of gas permeability of cement stone samples was carried out using GK-5 installation according to the method described in [26].

Determination of expansion deformation was carried out using add-on device to the consistometer (Fig. 2), which makes it possible to obtain the expansion curve of the plugging material at high temperatures and pressures. [26].

$\mathrm{X}$-ray phase analysis of the plugging stone was performed using DRON-2 installation with a copper cathode and a monochromator. The test material was stuffed into a cuvette with a diameter of $0.0275 \mathrm{~m}$ and a depth of $0.005 \mathrm{~m}$. During the analysis the cuvette was rotated around the axis at a constant speed of $20 \mathrm{~min}^{-1}$ [26].

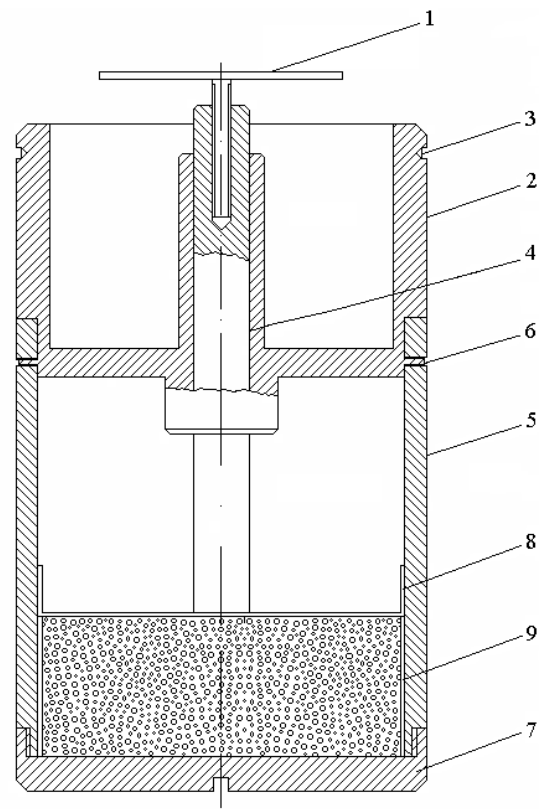

Fig. 2. Add-on device to the KC-3 consistometer to study the dynamics of cement samples expansion: plate-type regulator (1); frame (2); socket for mounting with a consistometer (3); plunger pair (4); cup frame (5); quick-removal connection (6); cup bottom (7); delimiter (8) and bush (9)

\section{Results and Discussion}

The performed researches were aimed to determine the composition of hydration products of weighted nonshrink plugging materials (WNPM), which hardened for a long time at high temperatures. These data allow us to assess the properties of cement stone and, therefore, to predict the isolation quality of well-casing annulus.

In our case, the content of silica in the mixture of high-calcium and acid ashes (1: 1) slightly exceeds the content of calcium oxide, and most likely, the formation of low-basic hydrosilicates of calcium occurs.

$\mathrm{X}$-ray patterns of cement stone, consisting of a high-calcium ash (CA), acid ash (AA) from Ladyzhyn plant $\left(\mathrm{AA}_{\mathrm{L}}\right)$ and Kurakhiv plant $\left(\mathrm{AA}_{\mathrm{K}}\right)$ are represented in Figs. 3 and 4 . The content of barite (B) varied from 50 to $60 \%[27]$.

Identification of hydration products composition of three-component plugging systems has caused significant difficulties. Ashes themselves are complex substances, especially high-calcium ash, and here the processes of interaction of all components of the plugging mixtures are considered. Identification of X-ray peaks was carried out in accordance with [28-31]. 
Analysis of the sample CA:AA $: B$ (Fig. 3, pattern 3 ) the hardening of which occurs at $393 \mathrm{~K}$ after 28 days, shows the presence of a number of low-basic calcium hydrosilicates, such as $\mathrm{C}_{2} \mathrm{~S}_{2} \mathrm{H}\left(2 \mathrm{CaO} \cdot 2 \mathrm{SiO}_{2} \cdot \mathrm{H}_{2} \mathrm{O}\right)$ and tobermorite $\quad \mathrm{C}_{5} \mathrm{~S}_{6} \mathrm{H}_{5} \quad\left(5 \mathrm{CaO} \cdot 6 \mathrm{SiO}_{2} \cdot 5 \mathrm{H}_{2} \mathrm{O}\right) \quad$ with corresponding interplanar distances $d=(1.85,2.49$, $3.79) \cdot 10^{-10} \mathrm{~m}$ and $d=(2.05,2.83,3.09,11.35) \cdot 10^{-10} \mathrm{~m}$, respectively. The presence of calcite $\mathrm{CaCO}_{3}$ with $d=$ $=(1.59,1.93,3.03,3.87) \cdot 10^{-10} \mathrm{~m}$, which is formed as a result of calcium oxide carbonization, is also observed. The pattern also shows traces of unreacted barite $\mathrm{BaSO}_{4}$ with $d=(1.63,1.67,2.28,2.55,2.73,3.58) \cdot 10^{-10} \mathrm{~m}$ and silica $\mathrm{SiO}_{2}$ with $d=(3.32,3.44,4.30) \cdot 10^{-10} \mathrm{~m}$. After 6 months of storage under similar conditions, the situation is almost unchanged. Some intensification of reflexes corresponding to tobermorite should be noted; we observed the decrease in the height of the peaks corresponding to silica, which reacts with hydrosilicates formed in the early stages of hydration.

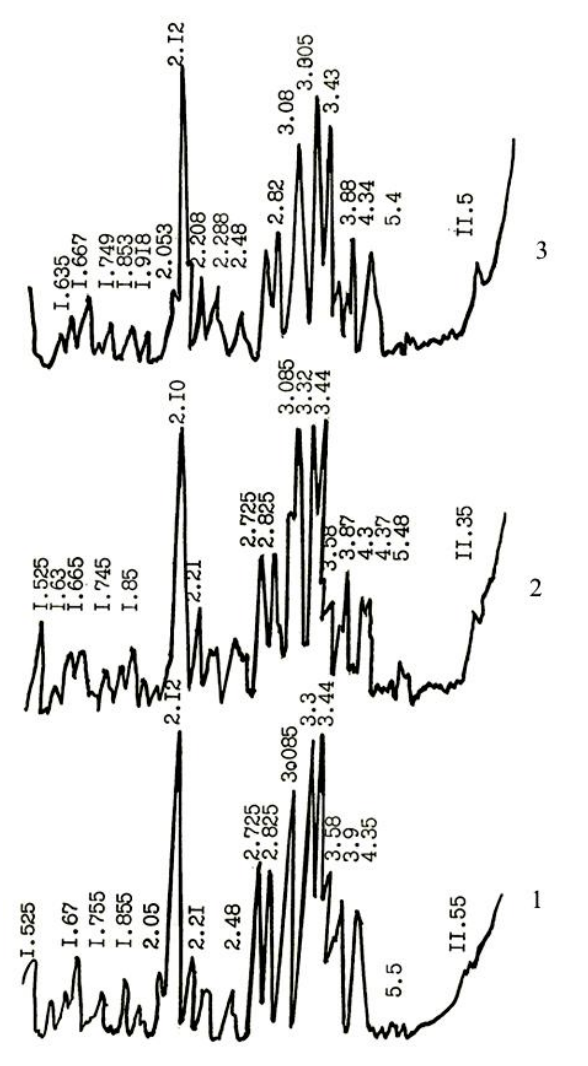

Fig. 3. X-ray pattern of plugging stone from WNPM: $\mathrm{CA}: \mathrm{AA}_{\mathrm{K}}: \mathrm{B}=20: 20: 60(1) ; \mathrm{CA}: \mathrm{AA}_{\mathrm{K}}: \mathrm{B}=25: 25: 50(2,3)$. Hardening conditions: $T=393 \mathrm{~K} ; P=50 \mathrm{MPa}$; after 28 days $(1,3)$ and after 180 days $(2)$
Similar composition of plugging material is presented in Fig. 4, with the only difference that the role of active mineral impurity is performed by the ash from Ladyzhyn SDPP. The compositions of both acid ashes differed slightly, and their different density and specific surface area, obviously, do not significantly affect the hydration processes. This is confirmed by the similarity of the patterns shape.

The change in barite amount also has not an essential effect on the composition of hydration products. The only thing that should be noted is the increase in the amount of unreacted $\mathrm{BaSO}_{4}(60 \%$ of barite in the mixture) and some increase in peaks corresponding to low-basic calcium hydrosilicates for the mixture with $40 \%$ of barite.

So, the resulting materials contain mainly lowbasic calcium hydrosilicates, calcium and unreacted compounds (barite and quartzite). This is the reason to predict their high heat resistance and strength. The absence of calcium hydroxide indicates the stability of the compositions in aqueous media, as well as in the media with high concentrations of $\mathrm{MgCl}_{2}$ and $\mathrm{MgSO}_{4}$.

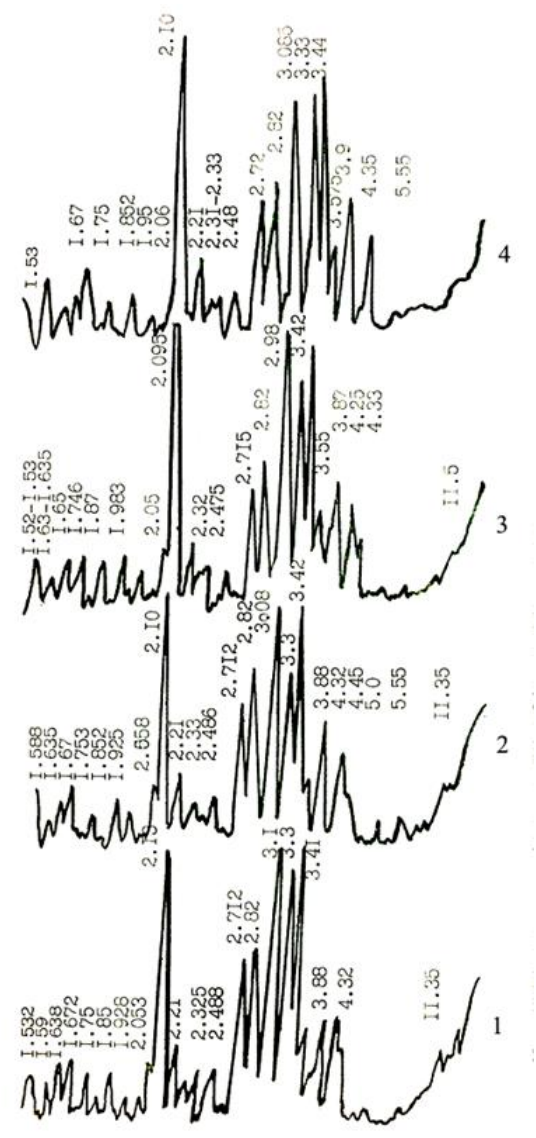

Fig. 4. X-ray pattern of plugging stone from WNPM: $\mathrm{CA}: \mathrm{AA}_{\mathrm{L}}: \mathrm{B}=25: 25: 50(1,2) ; \mathrm{CA}: \mathrm{AA}_{\mathrm{L}}: \mathrm{B}=30: 30: 40$ (3) and $\mathrm{CA}: \mathrm{AA}_{\mathrm{L}}: \mathrm{B}=20: 20: 60$ (4). Hardening conditions: $T=393 \mathrm{~K} ; P$ $=50 \mathrm{MPa}$; after 28 days $(1,3,4)$ and after 180 days (2) 
It was impossible to establish for these systems whether $\mathrm{BaSO}_{4}$ is the only inert filler, or participates in the reactions during long-term storage under stable hydrobarothermal conditions and thus contributes to the strength like hematite in UShC, where at high temperatures $(473 \mathrm{~K}) \mathrm{FeO}$ is replaced by $\mathrm{SiO}_{2}$ and ironsubstituted tobermorite is formed. These assumptions agree with the results of X-ray phase analysis.

The increase in the volume of the cement stone during the hardening period leads to the compaction of the filtration crust formed on the walls of the well and prevents the formation of channels in it, which occurs as a result of stone shrinkage. This creates a good contact of the cement ring with the well walls and casing. It was proved that cements with the expansion value of at least $1.95 \%$ are required to ensure the annulus impermeability in the presence of a filtration crust [26]. But the purpose of this study was somewhat broader: to obtain weighted non-shrink plugging materials, the compositions of which are represented in Tables 1 and 2. Among them only compositions with high-calcium ash are expandable ones.

The expansion of WNPM occurs due to the conversion of free $\mathrm{CaO}$ and $\mathrm{MgO}$ into corresponding hydroxides. The formed ettringite may also contribute to the increase in volume. It is very important that the expansion process occurs before the formation of a rigid coagulation-crystallization structure, i.e. in the period when the system is in a state capable of plastic deformation without destruction.

At high temperatures (above $393 \mathrm{~K}$ ) the formation of $\mathrm{Ca}(\mathrm{OH})_{2}, \mathrm{Mg}(\mathrm{OH})_{2}$ and ettringite occurs at the initial stage of hydration and ends within 1-3 h. Fig. 5 represents the kinetic curves of the WNPM expansion over time. Indeed, in $1-3 \mathrm{~h}$ the expansion process is almost complete. Thus, the possibility of the cement stone destruction in the late periods of hardening is excluded. The absolute value of expansion achieves maximum at high temperatures $(393-433 \mathrm{~K})$ and is lower at $348 \mathrm{~K}$. This can obviously be explained by the following. The main period of the increase in volume (at $348 \mathrm{~K}$ ) coincides with the dispersed state of the system, which is

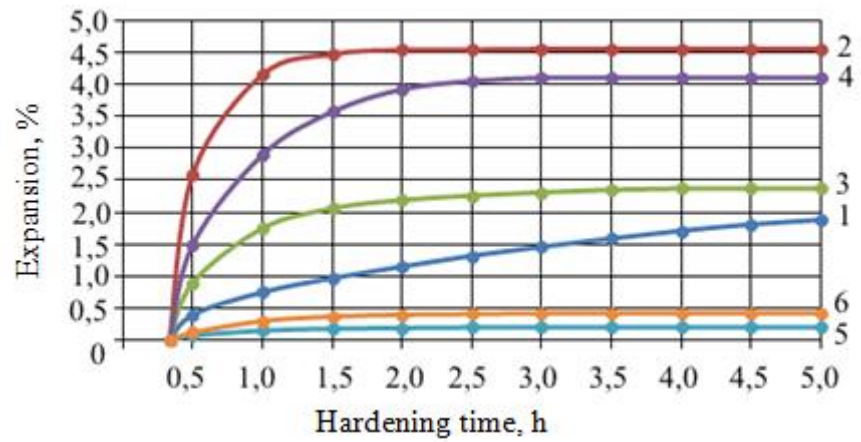

not yet capable of significant plastic deformations. The crystallization pressure in the expansion process is so significant that the increase in external pressure to $80 \mathrm{MPa}$ does not significantly affect the process and the results of expansion.

The introduction of a retarder does not reduce the expansion value, in contrast to potassium chloride, which is introduced into the mixing water to a state of saturation. We observed that the expansion of the mixture containing the ash from Kurakhiv SDPP is much higher (by 5-10 times) to compare with the mixture containing the ash from Ladyzhyn SDPP. The determined effect requires additional special studies.

There are different opinions, sometimes completely opposite, about the relationship between the strength of the cement stone and the insulation quality of the well annulus. Some authors consider requirements for the stone strength to be unreasonably high, because it can adversely affect the deformable properties. Kozhevnikov and Milechin [32, 33] give the minimum allowable value of the compressive strength of the plugging material equaled to $0.90-3.50 \mathrm{MPa}$ when meeting the requirements for other properties of the stone.

The variety of compositions studied in our work caused a rather significant variance in the results of bending/compressive strength measurements (Tables 1 and 2). The mechanical strength of cement stone depends on a number of factors, among which the main ones are the chemical and mineralogical composition of the mixture, the amount and composition of the mixing liquid, the hardening conditions. All these factors vary significantly in real conditions of well cementing.

The materials we studied included five different components, the water-mixture ratio varied from 0.25 to 0.33 , and in addition, some materials were mixed with a saturated solution of $\mathrm{KCl}$. Accordingly, the strength after 2 days of hardening differs by 3-3.5 times, and after 28 days - by 4 times. In general, 28-day strength is on average 2 times higher than 2-day strength. WNPM (WPM), which hardened at $T=433 \mathrm{~K}$, has the highest strength.

Fig. 5. Kinetics of expansion of weighted non-shrink plugging materials: $\mathrm{CA}: \mathrm{AA}_{\mathrm{K}}: \mathrm{B}=25: 25: 50, \mathrm{C}-3=2-3 \%(1-3)$; $\mathrm{CA}: \mathrm{AA}_{\mathrm{K}}: \mathrm{B}=25: 25: 50, \mathrm{C}-3=2-3 \%$, nitrilotrimethylphosphonic acid (NTP) $=0.05 \%$ (4); $\mathrm{CA}: \mathrm{AA}_{\mathrm{L}}: \mathrm{B}=25: 25: 50, \mathrm{C}-3=2-3 \%(5,6)$.

Hardening conditions: $T=348 \mathrm{~K}, P=30 \mathrm{MPa}(1,5)$;

$T=393 \mathrm{~K}, P=50 \mathrm{MPa}(2) ; T=433 \mathrm{~K}, P=60 \mathrm{MPa}(3,4)$ and $T=373 \mathrm{~K}, P=40 \mathrm{MPa}(6)$ 
Operational properties of the WPM based stone

\begin{tabular}{|c|c|c|c|c|c|c|c|c|c|c|c|c|c|c|}
\hline \multicolumn{6}{|c|}{ Components, wt \% } & \multirow[b]{3}{*}{ 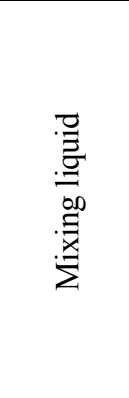 } & \multirow[b]{3}{*}{$\sum_{3}^{\sum}$} & \multirow[b]{3}{*}{ 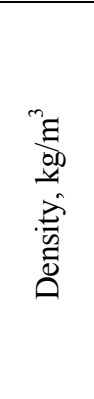 } & \multicolumn{6}{|c|}{ Bending/compressive strength, MPa } \\
\hline \multirow[b]{2}{*}{$\begin{array}{l}8 \\
\frac{1}{1} \\
\stackrel{5}{0} \\
2\end{array}$} & \multirow[b]{2}{*}{ 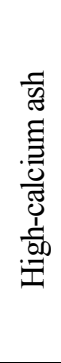 } & \multirow[b]{2}{*}{ 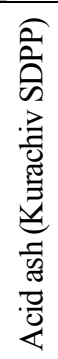 } & \multirow[b]{2}{*}{ 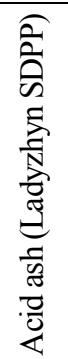 } & \multirow[b]{2}{*}{ 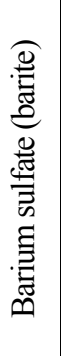 } & \multirow[b]{2}{*}{ 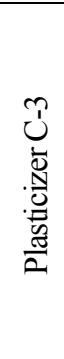 } & & & & $T=1$ & $48 \mathrm{~K}, P=$ & $0 \mathrm{MPa}$ & $T=3$ & $3 \mathrm{~K}, P=5$ & $\mathrm{MPa}$ \\
\hline & & & & & & & & & 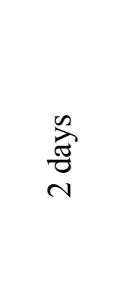 & 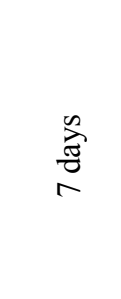 & 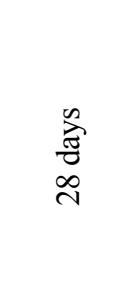 & $\underset{\sim}{\stackrel{0}{\vec{J}}}$ & 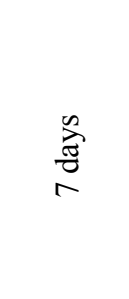 & 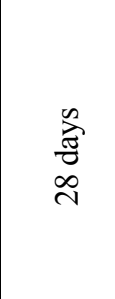 \\
\hline 50 & - & - & 50 & - & 2 & \multirow{3}{*}{ 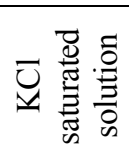 } & 0.28 & 1970 & $4.3 / 9.4$ & $5.8 / 12.1$ & $7.0 / 14.8$ & $5.4 / 10.0$ & $6.7 / 12.8$ & $9.0 / 18.3$ \\
\hline- & 25 & - & 25 & 50 & 1 & & 0.25 & 2230 & $2.3 / 6.6$ & $3.7 / 8.5$ & $3.9 / 11.0$ & $1.5 / 3.5$ & $2.3 / 5.1$ & $3.8 / 8.9$ \\
\hline- & 25 & 25 & - & 50 & 1 & & 0.33 & 1950 & $1.3 / 2.9$ & $3.2 / 8.9$ & $4.7 / 12.8$ & $1.7 / 4.0$ & $2.8 / 5.9$ & $4.3 / 9.0$ \\
\hline- & 25 & 25 & - & 50 & 2 & \multirow{3}{*}{$\frac{0}{\pi}$} & 0.28 & 2040 & $2.7 / 6.9$ & $3.3 / 7.3$ & $4.0 / 8.0$ & $1.8 / 3.1$ & $3.1 / 5.9$ & $3.3 / 6.2$ \\
\hline- & 20 & 20 & - & 60 & 2 & & 0.28 & 2110 & $1.6 / 3.5$ & $1.9 / 4.3$ & $3.5 / 6.1$ & $1.0 / 2.3$ & $1.7 / 3.9$ & $2.5 / 4.5$ \\
\hline- & 25 & - & 25 & 50 & 1 & & 0.25 & 2190 & $29 / 6.5$ & $3.6 / 8.5$ & 455112 & $1.0 / 2.1$ & $1.5 / 3.8$ & $2.7 / 4.3$ \\
\hline
\end{tabular}

Table 2

Operational properties of the WPM based stone

\begin{tabular}{|c|c|c|c|c|c|c|c|c|c|c|c|c|c|}
\hline \multicolumn{6}{|c|}{ Components, wt \% } & \multirow{3}{*}{ 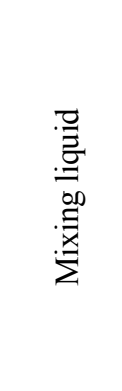 } & \multirow{3}{*}{$\sum_{i}$} & \multirow{2}{*}{\multicolumn{3}{|c|}{$\begin{array}{c}\text { Bending/compressive strength, } \\
\mathrm{MPa}\end{array}$}} & \multicolumn{3}{|c|}{$\begin{array}{l}\text { Gas permeability after } \\
2 \text { days, } \mu \mathrm{m}^{2} 10^{-3} \\
\end{array}$} \\
\hline \multirow{2}{*}{$\frac{8}{\frac{1}{1}}$} & \multirow{2}{*}{ 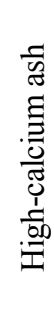 } & \multirow{2}{*}{ 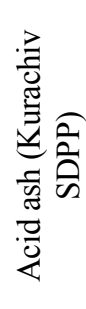 } & \multirow{2}{*}{ 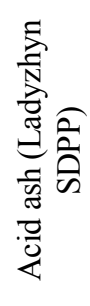 } & \multirow{2}{*}{ 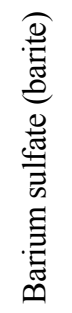 } & \multirow{2}{*}{ 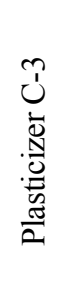 } & & & & & & \multirow{2}{*}{ 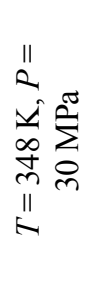 } & \multirow{2}{*}{ 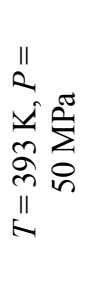 } & \multirow{2}{*}{ 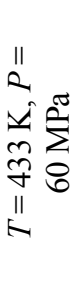 } \\
\hline & & & & & & & & 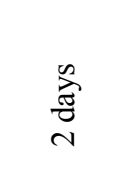 & 胥 & 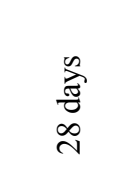 & & & \\
\hline 50 & - & - & 50 & - & 2 & \multirow{4}{*}{ 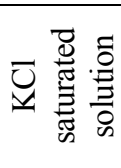 } & 0.28 & $3.1 / 7.5$ & $5.0 / 11.9$ & $7.1 / 16.7$ & 0.22 & 0.75 & 0.49 \\
\hline 25 & - & 25 & - & 50 & 1 & & 0.30 & - & - & $\begin{array}{llll}- & \end{array}$ & 0.36 & 1.15 & 0.82 \\
\hline- & 25 & - & 25 & 50 & 1 & & 0.25 & $3.4 / 7.4$ & $4.6 / 8.5$ & $5.1 / 11.0$ & 1.96 & 2.40 & 2.12 \\
\hline- & 25 & 25 & - & 50 & 1 & & 0.33 & $2.3 / 4.8$ & $3.5 / 7.1$ & $3.8 / 7.5$ & 2.14 & 2.50 & 1.81 \\
\hline- & 25 & 25 & - & 50 & 2 & \multirow{3}{*}{$\stackrel{0}{\pi}_{3}^{\pi}$} & 0.28 & $1.7 / 3.3$ & $5.3 / 10.8$ & $5.7 / 12.5$ & 0.82 & 1.17 & 1.14 \\
\hline- & 20 & 20 & - & 60 & 2 & & 0.28 & $1.6 / 3.0$ & $3.0 / 5.9$ & $3.6 / 7.5$ & 0.48 & 2.10 & 1.36 \\
\hline- & 25 & - & 25 & 50 & 1 & & 0.25 & $3.3 / 6.3$ & $4.5 / 8.5$ & $5.0 / 9.6$ & 1.29 & 1.98 & 1.36 \\
\hline
\end{tabular}

We have made assumptions about the possibility of barite participation in cement hydration reactions and its influence on the strength of cement stone. Based on the results obtained, this hypothesis should be considered quite real. There are two possible ways of WNPM reaction with barite. This is either the formation of baritesubstituted calcium hydrosilicates, or the crystallization of complex compounds based on calcium hydroaluminates.

The materials containing acid ash of Ladyzhyn SDPP as a siliceous impurity have higher strength compared with those with acid ash of Kurakhiv SDPP. This is due to the higher water-mixture ratio of the latter.
Moreover, during hardening, the degree of expansion of the compositions with Kurakhiv ash is higher. Thus, they have greater porosity, which may also affect the strength.

At $348 \mathrm{~K}$ and $393 \mathrm{~K}$ the samples mixed with a saturated solution of potassium chloride has a lower strength in comparison with that of the samples mixed with fresh water. The increase in temperature to $433 \mathrm{~K}$ leads to the equalization of physical and mechanical characteristics.

The permeability of plugging stone is the most important operational characteristic. Dense lowpermeability stone has a good resistance in aggressive waters and prevents alkaline corrosion. In some cases, the 
high permeability of the cement ring can cause flooding of wells and oil (gas) overflow from productive horizons.

Today, the permeability of plugging stone is not regulated, but some researchers $[34,35]$ believe that for high-quality insulation of the annulus the materials with permeability of less than $(2-4) \cdot 10^{-3} \mu \mathrm{m}^{2}$ should be used.

As a rule, there is a correlation between the strength and permeability of plugging stone. This assumption is confirmed by the data of Tables 1 and 2 . With increasing strength, the gas permeability decreases, although there are some exceptions. For almost all samples, the maximum gas permeability is observed at $393 \mathrm{~K}$ (the strength is the lowest except for compositions with Portland cement). The lowest permeability is observed for the compositions, the mixing fluid of which is a saturated solution of potassium chloride. In the first case this can be explained by a significant increase in volume (i.e., the increase in porosity) at $393 \mathrm{~K}$. In the second case, on the contrary, by pores clogging due to the components synthesized with the participation of potassium ions.

All values of gas permeability given in Table 2 meet the required values and in some cases even exceed them. Gas permeability of WNPM is by 1.5-2 times lower than that of standard weighted cements such as UShC and UCG.

\section{Conclusions}

The composition of hydration products of weighted non-shrink cement materials (mixtures that hardened for a long time at high temperatures) was determined by the Xray phase analysis. It has been established that during WNPM hardening the formed products contain a number of low-basic calcium hydrosilicates of the $\mathrm{C}_{2} \mathrm{~S}_{2} \mathrm{H}$ $\left(2 \mathrm{CaO} \cdot 2 \mathrm{SiO}_{2} \cdot \mathrm{H}_{2} \mathrm{O}\right)$ type and tobermorite. This allows to predict high heat resistance and strength of the plugging stone. At the same time, the absence of calcium hydroxide indicates the stability of the compositions in aqueous media, as well as in media with high concentrations of $\mathrm{MgCl}_{2}$ and $\mathrm{MgSO}_{4}$.

Analysis of the kinetic curves of the plugging material expansion during the hardening process shows: (i) the expansion process is almost completed in 1-3 $\mathrm{h}$; (ii) the expansion is maximum at high temperatures (393$433 \mathrm{~K}$ ) and low at $348 \mathrm{~K}$; (iii) potassium chloride, which is introduced into the mixing water, inhibits the growth of the plugging stone volume.

The technological properties of plugging stone depend on physicochemical factors, in particular, the composition of the plugging material, temperature, pressure and hardening time. The following peculiarities were determined: 28-day strength of the stone is on average by 2 times higher than 2-daily strength; WNPM hardened at $433 \mathrm{~K}$ have the highest strength; the gas permeability of the cement stone obtained on the basis of the proposed compositions is in the range of $(0.22-2.50) \cdot 10^{-3} \mu \mathrm{m}^{2}$, which is sufficient for high-quality insulation of wells. We assumed the possibility of barite participation in cement hydration reactions and its impact on the strength of cement stone. There are two directions in which the reactions of the WNPM components with barite could proceed. This is either the formation of baritesubstituted calcium hydrosilicates, or the crystallization of complex compounds based on calcium hydroaluminates.

The result of this work is the creation of a new class of plugging materials - weighted non-shrink (expandable) mixtures with a density of $1950-2230 \mathrm{~kg} / \mathrm{m}^{3}$. WNPM were created on the basis of fly ash from TPP, weighting additive and superplasticizer. Regarding the operational parameters, the resulting WNPM surpass all known weighed plugging cements. They have high heat resistance, high strength, low permeability, absence of shrinkage (expansion) during hardening, a wide range of density.

The application of WNPM (WPM) will ensure the high quality of well fixing in AHFP zones. WNPM mixed with a saturated solution of potassium chloride will be effectively used in the areas of saline deposits. WPM were successfully tested during flow string cementing on two wells of the association "Poltavanaftogazgeologiya".

In further research, it is advisable to take into account the specific conditions of oil and gas wells in the Dnieper-Donetsk basin, which have a promising geothermal resource [36].

\section{List of abbreviations:}

AHFP - abnormally high formation pressure

UCG-1, UCG-2 - weighted cement for high temperatures

USHC-1-120, USHC-2-120, USHC-1-200, USHC-2-200 weighted slag cement

PCT-I-100, PCT-II-100 - plugging Portland cement

SDPP - a state district power plant

TPP - thermal power plant

WPM - weighted plugging materials (plugging Portland cement is a binder)

WNPM - weighted non-shrink plugging materials (highcalcium ash is a binder)

MF-AR - a superplasticizer based on melamine formaldehyde resin

C-3 - superplasticizer based on naphthalene

formaldehyde resin

$\mathrm{CA}$ - high-calcium ash

AA - acid ash (source of silica)

$\mathrm{AA}_{\mathrm{L}}$ - acid ash from Ladyzhyn SDPP

$\mathrm{AA}_{K}-$ acid ash from Kurakhiv SDPP

$\mathrm{B}$ - barium sulfate (barite) 
$\mathrm{C}-\mathrm{CaO}$

$\mathrm{S}-\mathrm{SiO}_{2}$

$\mathrm{H}-\mathrm{H}_{2} \mathrm{O}$

(A) - modification of calcium hydrosilicates

\section{References}

[1] Malyovanyy M., Sakalova G., Chornomaz N., Nahurskyy O. Chem. Chem. Technol., 2013, 7, 355.

https://doi.org/10.23939/chcht07.03.355

[2] Sakalova H., Malovanyy M., Vasylinych T., Kryklyvyi R.: J. Ecol. Eng., 2019, 1, 158. https://doi.org/10.12911/22998993/93944

[3] Sakalova H., Malovanyy M., Vasylinycz T. et al.: J. Ecol. Eng., 2019, 4, 167. https://doi.org/10.12911/22998993/102841

[4] Malovanyy M., Palamarchuk O., Trach I. et al.: J. Ecol. Eng., 2020, 7, 178. https://doi.org/10.12911/22998993/125545

[5] Zelenko Yu., Malovanyy M., Tarasova L.: Chem. Chem. Technol., 2019, 2, 218. https://doi.org/10.23939/chcht13.02.218

[6] Biliaiev M., Rusakova T., Kolesnik V., Pavlichenko A.: Nauk. Visnyk Nats. Khirn. Univ., 2017, 3, 100.

[7] Kolesnik V., Pavlichenko A., Borysovs'ka O., Buchavy Yu.: Solid State Phenom., 2018, 277, 178.

https://doi.org/10.4028/www.scientific.net/SSP.277.178

[8] Malovanyy M., Lyashok Y., Podkopayev S. et al.: J. Ecol. Eng., 2020, 2, 95. https://doi.org/110.12911/22998993/116339

[9] Plyatsuk L., Balintova M., Chernysh Y. et al.: Lect. Notes Mech. Eng., 2020, 843. https://doi.org/10.1007/978-3-030-22365-6_84 [10] Telak O., Popovych V., Zachko O., Korol K.: E3S Web Conf. V International Innovative Mining Symposium, 2020, 174, 02006. https://doi.org/10.1051/e3sconf/202017402006

[11] Popovych V., Stepova K., Prydatko O.: MATEC Web of Conferences, 247, 00025. FESE 2018.

https://doi.org/10.1051/matecconf/201824700025

[12] Sanytsky M., Sobol K., Shcturmay M., Khymko O.: Chem. Chem. Technol., 2011, 5, 227.

https://doi.org/10.23939/chcht05.02.227

[13] Marushchak U., Sanytsky M., Pozniak O., Mazurak O.: Chem. Chem. Technol., 2019, 13, 510.

https://doi.org/10.23939/chcht13.04.510

[14] Tershak B.: Sci. Bull. Ivano-Frankivsk National Technical University of Oil and Gas, 2010, 1, 52.

http://nv.nung.edu.ua/index.php/nv

[15] Kang H-M., Shin M-Y., Kim S-K. et al.: Suggested Tamping Materials for Short Length Blast Holes in Explosive Demolition Operations [in:] Singh P., Sinha A. (Eds.), Rock Fragnentation by Blasting: Fragblast 10. Taylor \& Francis Group, London 2013.

[16] Ortega J., Pastor J., Albaladejo A. et al.: Materiales de Construcción, 2014, 64, e003. https://doi.org/10.3989/mc.2014.04912 [17] Lübeck A., Gastaldini A., Barin D., Siqueira H.: Cem. Concr. Comp., 2012, 34, 392.

https://doi.org/10.1016/j.cemconcomp.2011.11.017

[18] Agzamov F., Izmuhambetov B., Tokunova E.: Khimiya

Tamponazhnykh i Promyvochnykh Rastvorov. Nedra, Moskva 2011.

[19] Orlovskyi V.: Hirnychyi Visnyk, 2015, 100, 96.

[20] Nizamutdinov E.: Nauka, Obrazovanie i Kultura, 2017, $2,5$.

[21] Agzamov F., Davletshin R., Belyaeva E.: Neftegazovoe Delo, 2017, 15, 8 .

[22] Kamalova Z., Rahimov R., Ermilova E., Stoyanov O.: Vestnik Kazanskogo Tehnologicheskogo Universiteta, 2013, 148. https://cyberleninka.ru/article/n/superplastifikatory-v-tehnologiiizgotovleniya-kompozitsionnogo-betona

[23] Lozhkin V.: Mezhdunarod. Zh. Prikladnykh Fundament.

Issledovaniy, 2013, 11, 109.

[24] Izotov V., Sokolova Yu.: Khimicheskie Dobavki dlya

Modifikatsii Betona. Paleotip, Kazan 2006.

[25] Ortega J., Sánchez I., Climent M.: Materiales de Construcción,

2013, 63, 219. https://doi.org/10.3989/mc.2012.06111

[26] Orlovskyi V.: Tamponazhni Materialy, shcho Rozshyriuiutsia pry Tverdinni. PoltNTU im. Yu. Kondratiuka, Poltava 2015.

[27] Orlovskyi V., Pokhylko A., Krytskyi V.: Geotekhnolohii, 2018, $1,44$.

[28] Berger M., Hubbell J., Seltzer S. et al.: NIST Standard Reference Database 8 (XGAM). https://doi.org/10.18434/T48G6X

[29] Voroshilov Yu., Pavlishin V.: Osnovy Kristallografii i

Kristallokhimii. Rentgenografiya Kristallov. KNT, Kyiv 2011.

[30] Lavina B., Dera P., Downs R.: Modern X-ray Diffraction Methods in Mineralogy and Geosciences. [in:] Spectroscopic Methods in Mineralogy and Materials Sciences. Rev. Mineralogy Geochem., 2014, 78, 1. https://doi.org/10.2138/rmg.2014.78.1

[31] Glusker J., Trueblood K.: Crystal Structure Analysis. Oxford University Press 2010.

[32] Kozhevnikov E.: Vestnik Permskogo natsionalnogo issledovatelskogo politehnicheskogo universiteta. Geologiya, neftegazovoe i gornoe delo, 2015, 17, 24.

https://cyberleninka.ru/journal/n/vestnik-permskogo-natsionalnogoissledovatelskogo-politehnicheskogo-universiteta-geologiyaneftegazovoe-i-gornoe-delo?i=1060942

[33] Melehin A., Chernyishov S., Turbakov M.: Neftyanoe

Hoziaystvo, 2012, 3, 50.

[34] Nikolaev N., Kozhevnikov E.: Vestnik Permskogo natsionalnogo issledovatelskogo politehnicheskogo universiteta. Geologiya.

Neftegazovoe i Gornoe Delo, 2014, 11, 29.

https://doi.org/10.15593/2224-9923/2014.11.3

[35] Souza P., Soares R., Anjos M. et al.: Brazilian J. Petrol. Gas, 2012, 6, 105.

[36] Fyk M., Biletsky V., Abbud M.: E3S Web of Conferences. Ukrainian School of Mining Engineering, 2018, 60, 00006. https://doi.org/10.1051/e3sconf/20186000006

Received: May 28, 2020 / Revised: June 13, 2020 / Accepted: August 13, 2020

\section{ФІЗИКО-ХІМІЧНІ ОСОБЛИВОСТІ ГІДРАТАЦЇ̈ ОБВАЖНЕНИХ ТЕРМОСТІЙКИХ ТАМПОНАЖНИХ МАТЕРІАЛІВ}

\begin{abstract}
Анотація. Створено новий конкурентоздатний клас тампонажних композицій (обважнені безусадкові тампонажні матеріали) із використанням як компонентів золи виносу TEC, обважннювача і суперпластифікатора. Рентгенофазовим аналізом тампонажного каменю ідентифіковано склад новоутворень в процесі гідратації розроблених тампонажних композиuій. Отримано кінетичні криві розширення тампонажного матеріалу в широкому температурному інтервалі. Визначено раціональні температурні режими тужавіння тампонажних композииій за критеріями міџності і газопроникності цементного каменю.
\end{abstract}

Ключові слова: цементування свердловин, тампонажний матеріал, гідратація ијементу, зола виносу, водосумішеве відношення, цементний камінь. 